\title{
Dividend Announcement Effect To Market Reaction in Non-Financial Companies Listed on Indonesia Stock Exchange Alvin Fabian ${ }^{1}$, Eko Budi Santoso ${ }^{2}$ \\ Accounting Study Program, Universitas Ciputra, Surabaya, Indonesia ${ }^{1}$ \\ E-mail: afabian01@student.ciputra.ac.id ${ }^{1}$, esantoso@ciputra.ac.id ${ }^{2}$
}

\begin{abstract}
This study aims to examine the differences in market reaction before and after the announcement of dividend omissions and dividend initiations in nonfinancial companies listed on the Indonesia Stock Exchange in 2016-2018. The sample used in this study was 71 companies consisting of 26 companies that announced dividend omissions and 45 companies that announced dividend initiations. The sample was determined using the purposive sampling method. This study used the event study method with an event window period of 5 days before the announcement, the announcement day, and 5 days after the announcement. The Wilcoxon Signed Ranks Test results in this study indicate that there are no differences in market reaction before and after the announcement of dividend omissions. Meanwhile the announcement of dividend initiations shows that there are differences in market reaction before and after the announcement of dividend initiations.
\end{abstract}

Keywords: Event study, Dividend Omissions, Dividend Initiations, Abnormal Return

\section{INTRODUCTION}

Every country has a dream to have a developed and rapidly developing capital market in their country. The capital market is an effective means of attracting funds from investors, which is then channeled back to productive sectors (Delikartika \& Ferry, 2017). The existence of the capital market in Indonesia is an important factor in developing the country's economy. The condition of the Indonesian capital market in the past few years has experienced developments in the current global economic conditions.

The development of the stock market from 2016 to 2018 experienced a growth reflected in the rise in market capitalization value and the Composite Stock Price Index (CSPI). This development certainly cannot be separated from stock trading activities carried out by investors in Indonesia.

According to the Badan Pusat Statistik (2019), Gross Domestic Product (GDP) is one important indicator to inform the economic conditions of a country in a certain period. The increase in GDP that occurred is certainly also a result of adding value to all companies operating in Indonesia. The benefit of the company indicates that the company's performance was good at that time. Therefore, the company should be able to provide strong trust and desire for investors to invest in the company (Rahayu \& Dana, 2016).

Every time buying and selling activities on the stock market, investors certainly have a goal to get a return that can be in the form of capital gains or dividends. Dividend distribution policy is closely related to influencing corporate financial and investment decisions. The careful calculation of company management for dividend distribution policy is a big challenge for any company (Anwar et al., 2017). The distribution of dividends made by companies must be 
Alvin Fabian \& Eko Budi Santoso / Dividend Announcement Effect To Market Reaction In Non Financial Companies Listed On Indonesia Stock Exchange

JAEF, Vol. 1, No 2. April 2020 pp 57-67

determined by decisions through dividend policy (Dewi \& Sedana, 2018). Dividend policies can take the form of, for example, a company announcing dividend distribution policies for the first time in a number of years not dividend initiations or a company announcing not distributing dividends for the first time after several years of dividend omissions.

According to Pramana \& Abundanti (2017), dividend announcements are often considered to have information content if the market reacts when the announcement is received by the market. The concept known as dividend signaling theory (Anwar et al., 2017). Because of the information content that gives a meaningful signal, dividend announcements can affect market reactions that are reflected by changes in stock prices. Indicators of abnormal return measurements can measure changes in stock prices because of dividend announcements reacted by the market (Kayana, et al., 2018).

Allegations of information content in dividend announcements have become an interesting issue to study. The motivation of researchers to conduct research on this topic is based on the following reasons. First, Indonesia's economic conditions have improved marked by an increase in Gross Domestic Product (GDP) from 2014 to 2018, an indicator that companies in Indonesia are doing well. With this good performance, the company should be able to get as much profit as possible, which will later be distributed, to investors in the form of dividends.

Second, the researcher wants to find out whether investors who conduct stock trading activities in the Indonesian capital market can make the right decision in responding to the signals of dividend announcements by existing issuers. According to the research of Dong et al. (2019), the results found show that the announcement of a dividend reduction or dividend omissions does not significantly influence stock returns. Research conducted by Lee \& Mauck (2016) shows that the results of empirical evidence about this research have a positive market reaction to the announcement of dividend initiations.

According to dividend signaling theory, companies that announce to pay cash dividends for the first time (dividend initiations) are described as a good signal because the company provides information that the company is in good profit prospects and the market will react positively. Whereas companies that announce not to pay cash dividends after several years of dividend distribution are described as a bad signal because the company is considered to have poor profit prospects and usually the market will react negatively.

However, companies that do not carry out dividend omissions policies are not considered as an unqualified company (Pertiwi \& Wirama, 2019). Logically, it is possible for companies that do not distribute dividends to choose to reinvest and choose to develop their companies. If in these circumstances, the market should react positively and consider the elimination of dividends as a good signal because the company chose to expand its business for the sake of good profit prospects in the future.

In line with current technological developments, investors should be easier to make decisions because investors can access financial reports, stock trends, read news and assess the company's stock returns (Tandio \& Widanaputra, 2016). For these reasons, the researcher wants to test whether dividend announcements influence market reactions. The purpose of this study 
Alvin Fabian \& Eko Budi Santoso / Dividend Announcement Effect To Market Reaction In Non Financial Companies Listed On Indonesia Stock Exchange

JAEF, Vol. 1, No 2. April 2020 pp 57-67

is to determine whether there are differences in market reactions before and after the announcement of dividend omissions and dividend initiations.

\section{Previous research and hypotheses}

Research conducted by Cotter et al. (2018) states that it does not find that dividend omissions do not have a statistically significant effect on price changes, confirms thatdividend omissions are not considered as shocking information to the market when compared to dividend initiations. Dong et al. (2019) conducted a study which said that the announcement of dividend reduction did not significantly influence stock returns comparing similar companies in China. Whereas the different results from Darmawan's research (2018) showed that in the event of dividend announcements a significant market reaction was found. At the announcement of dividend omissions there were 3 observations that were significant and in accordance with the theory and occurred a time lag.

The results of Pertiwi \& Wirama's research (2019) also show the results that the market reacts negatively to dividend omissions. Announcement of dividend omissions can certainly provide information for investors and can be reacted by the market. A reacting market can be characterized by changes in abnormal returns that occur before and after the announcement of dividend omissions. The existence of inconsistent results from some previous studies makes researchers want to reexamine the difference in market reaction due to the announcement of dividend omissions. Therefore the first hypothesis of this study are:

H1: There are differences in market reaction before and after the announcement of dividend omissions.

The results of Lee \& Mauck's (2016) study show that empirical evidence about this research has a positive market reaction to the announcement of dividend initiations and an increase in dividends in companies with higher and lower levels of special volatility. Mrzyglod \& Nowak (2017) said that in terms of increasing dividends and dividend payments for the first time (dividend initiations), had a significant positive effect on the release of stock price news and were noticed on the first day after the announcement that occurred on the Warsaw Stock Exchange (WSE). The same results obtained from the study of Yu \& Webb (2017), namely the existence of a positive market response from the announcement of dividend initiations by technology sector companies.

In addition, research from Lavista et al. (2018) and Lestari et al. (2018) says that there are differences in abnormal returns around the day of the cum-dividend date. Announcement of dividend initiations is usually considered a good signal by investors because it is considered a good company performance and is able to distribute dividends to its shareholders. The existence of this information will certainly make the market react, which is marked by the difference in abnormal returns before and after the announcement of dividend initiations. Therefore the second hypothesis of this research is:

H2: There are differences in market reaction before and after the announcement of dividend initiations. 
Alvin Fabian \& Eko Budi Santoso / Dividend Announcement Effect To Market Reaction In Non Financial Companies Listed On Indonesia Stock Exchange

JAEF, Vol. 1, No 2. April 2020 pp 57-67

\section{METHOD}

This study aims to examine whether there are market differences at the time before and after the announcement of dividends consisting of dividend omissions and dividend initiations. This study uses a quantitative approach. Quantitative research methods according to Sugiyono (2015: 14) can be interpreted as a research method based on the philosophy of positivity, used to examine specific populations or samples. The analytical tool used by researchers is the different test (t-test) if the data is normally distributed. Meanwhile, if the data is not normally distributed, the Wilcoxon Signed Ranks Test will be conducted. This study uses the event study method to analyze dividend announcements on market reactions. Based on these criteria, researchers got a result of 929 companies over a period of 2016-2018 for observation. The population used in this study is non-financial companies listed on the Indonesia Stock Exchange, amounting to 563 companies. The sampling technique used in this study uses purposive sampling technique. Criteria for selection of sample companies that make dividend omissions announcements are:

1. Non-financial companies listed on the Indonesia Stock Exchange (IDX) during the study period, namely from 2014 - 2018.

2. The company does not distribute cash dividends after a minimum of two consecutive years distributing cash dividends during 2016 - 2018 (to avoid lack of data availability on the IDX).

3. The company does not carry out other corporate actions (stock dividends, right issues, stock split, reverse stock split, buy back, bonus shares, mergers, acquisitions, etc.) that can affect stock prices during the window period.

Meanwhile the criteria for selecting sample companies that make dividend initiations announcements are:

1. Non-financial companies listed on the Indonesia Stock Exchange (IDX) during the study period, namely from 2014 - 2018.

2. The company distributes cash dividends after at least two consecutive years of not dividing dividends during the study period (to avoid lack of data availability on the IDX).

3. The company does not carry out other corporate actions (stock dividends, right issues, stock split, reverse stock split, buy back, bonus shares, mergers, acquisitions, etc.) that can affect stock prices during the window period.

Based on these criteria, researchers got a result of 26 companies announced dividend omissions and 45 companies announced dividend initiations over a period of 2016-2018 for observation.

\section{Definition of Variable Operations}

Dividend Omission is an Event where a company does not distribute cash dividends after a minimum of two consecutive years distributing cash dividends. The date of the dividend omissions event is determined from the date of the AGM. 
Alvin Fabian \& Eko Budi Santoso / Dividend Announcement Effect To Market Reaction In Non Financial Companies Listed On Indonesia Stock Exchange

JAEF, Vol. 1, No 2. April 2020 pp 57-67

Dividend Initiations Corporate events distribution of cash dividends back after at least two consecutive years not distributing cash dividends. The date of the event dividend initiations is determined from the date of the implementation of the cum-dividend.

Abnormal return is calculated by finding the difference between actual return and expected return. Expected returns are calculated using the market adjusted model so that the estimated return is the same as the market index return (CSPI). The following is the formula for calculating abnormal returns:

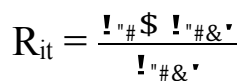

$$
\begin{aligned}
& \mathrm{E}\left(\mathrm{R}_{\mathrm{i}, \mathrm{t}}\right)=\mathrm{R}_{\mathrm{M}, \mathrm{t}}=\frac{()^{*}+_{\#} \$()^{*}+_{\# \&} \cdot}{()^{*}+_{\# \&} \cdot} \\
& \mathrm{RTN}_{\mathrm{i}, \mathrm{t}}=\mathrm{R}_{\mathrm{i}, \mathrm{t}}-\mathrm{E}\left(\mathrm{R}_{\mathrm{i}, \mathrm{t}}\right)
\end{aligned}
$$

\section{RESULTS}

\section{Descriptive Statistics}

Descriptive statistics can consist of minimum, maximum, mean, median and standard deviation can show the lowest and highest values, the average value, the middle value and the distribution of data in the data studied. Table 1 shows that the AAR (Average Abnormal Return) before the announcement of dividend omissions and the AAR after the announcement of dividend omissions which are used as proxies to measure the existence of market reactions each have an average value of 0,0015 and 0,0023. From the mean, we can see that both are positive and there is no significant difference from the mean value of AAR before the announcement and the AAR after the announcement. Therefore, it can be interpreted if there is no difference in market reaction before and after the announcement of dividend omissions. The minimum value on AAR before the announcement is $-0,02$ while the AAR after the announcement is 0,03 . The median value for AAR before the announcement is $-0,00056$ and for the median value for the AAR after the announcement is 0,00067 . The maximum value of the table above is 0,03 in the AAR before the announcement and 0,06 in the AAR after the announcement. The standard deviation values in the table above are 0,00925 in AAR before the announcement and 0,01728 in the AAR after the announcement of dividend omissions.

Table 2 shows that the AAR before the announcement of dividend initiations and AAR after the announcement of dividend initiations which are used as proxies to measure the existence of market reactions each have an average value of 0,0019 and $-0,0060$. From the mean, we can see that there is a change in the average value from a positive number to a negative number. This means that there are differences in the mean before and after the announcement of dividend initiations. The median value of the AAR before the announcement is 0,00062 and the median value of the AAR after the announcement is $-0,00743$. The minimum value on the 
Alvin Fabian \& Eko Budi Santoso / Dividend Announcement Effect To Market Reaction In Non Financial Companies Listed On Indonesia Stock Exchange

JAEF, Vol. 1, No 2. April 2020 pp 57-67

AAR before the announcement is $-0,02$ while the AAR after the announcement is $-0,04$. The maximum value of the table above is 0,04 in the AAR before the announcement and 0,03 in the AAR after the announcement. The standard deviation values in the table above are 0,01315 before the announcement and 0,01407 after the announcement of dividend initiations.

\section{Normality Test}

Normality test is conducted to determine whether the data in this study are normally distributed or not. Data is said to be normally distributed if the significance value is greater than 0,05. Testing the normality of data using Kolmogorov-Smirnov with the help of SPSS 20. In table 3, it shows that the data from the average abnormal return on the announcement of dividend omissions are not normally distributed because the significance value is 0,000 (less than 0,05$)$.

In table 4 above, we can see that the data from average abnormal returns on dividend initiations announcements have data that are not normally distributed because the significance value is 0,000 (smaller than 0,05). Researchers use the Wilcoxon Signed Ranks Test to testthe first and second hypotheses because the data on the announcement of dividend omissions and dividend initiations are not normally distributed. Data that are not normally distributed may be caused by market anomalies such as large companies but small returns or conditions such as the Monday effect and the January effect. What is meant by large companies is companiesthat have a complex organizational structure, the percentage of business failure is relatively low, and long-term capital is relatively easier to obtain for business development.

\section{The Wilcoxon Signed Ranks Test}

The first hypothesis in this study is that there are differences in market reactions before and after the announcement of dividend omissions. The statistical test used is the Wilcoxon Signed Ranks Test because the data is not normally distributed. The test is used to determine whether there are differences before and after the announcement of dividend omissions. The first hypothesis testing is based on the day of the event 5 days before and 5 days after the announcement of the GMS. This test uses a 95\% confidence level with a significance level of $5 \%$ or asymptotic significance (2-tailed) $<0,05$. The test results can be seen in table 5 . In the Wilcoxon Signed Ranks Test results above we can see that the results of the statistical tests above show that there is no difference in market reaction before and after the announcement of dividend omissions because they have a significance level of 0,781 which is greater from 0,05 .

The second hypothesis in this study is that there are differences in market reactions before and after the announcement of dividend initiations. The statistical test used is the Wilcoxon Signed Ranks Test because the data is not normally distributed. The test is used to determine whether there are differences before and after the announcement of dividend initiations. The second hypothesis testing is based on the day of the event 5 days before and 5 days after the cum-dividend date. This test uses a $95 \%$ confidence level with a significance level of $5 \%$ or asymptotic significance $(2$-tailed) $<0,05$. The test results can be seen in table 6 . In the Wilcoxon Signed Ranks Test results above we can see that the results of the statistical tests above indicate 
Alvin Fabian \& Eko Budi Santoso / Dividend Announcement Effect To Market Reaction In Non Financial Companies Listed On Indonesia Stock Exchange

JAEF, Vol. 1, No 2. April 2020 pp 57-67

there are differences in market reactions before and after the announcement of dividend initiations because they have a significance level of 0,014 which is smaller than 0,05 .

\section{DISCUSSION}

\section{Dividend Omissions Discussion}

Based on the results of statistical tests on the first hypothesis shows that there are no differences in market reaction before and after the announcement of dividend omissions. The average value of the average abnormal return before and after the event shows a positive number that is 0.0015 and 0.0023 contained in table 1 . The positive abnormal return shows that investors still have a sense of optimism about companies that decide to use their profits as funds to reinvest the company itself. It should be able to cause investors to feel optimistic about companies that decide not to distribute dividends after several years of dividend distribution (Darmawan, 2018). Another factor affecting the condition of the Indonesian economy that is experiencing growth in 2016-2018 is another factor that can cause investors to feel optimistic about the company that decided not to distribute dividends because the company wants to reinvest for future company growth.

The results of this study do not support the dividend signaling theory because in the announcement of dividend omissions there is no difference in abnormal returns before and after the announcement. The absence of differences in market reaction before and after the announcement of dividend omissions indicates that the announcement of dividend omissions is not an important information for investors. Because investors perceive information from announcements of dividend omissions as not important information, there is no difference in market reactions before and after announcing dividend omissions (Cotter et al., 2018).

The results in this study are in line with research studies conducted by Dong et al. (2019) and Cotter et al. (2018) which says that dividend omissions have no significant effect on stock prices so there is no difference in market reaction before and after the announcement. But the results of this study are not in line with the research of Darmawan (2018) and Pertiwi \& Wirama (2019) which say that dividend omissions have an influence on stock prices.

\section{Dividend Initiations Discussion.}

Based on the results of statistical tests on the second hypothesis shows that there are differences in market reaction before and after the announcement of dividend initiations. The average average abnormal return before and after the announcement of dividend initiationshas decreased from 0.019 to -0.060 which can be seen in table 2. Positive abnormal returns before the announcement indicate that investors are competing to buy shares of an issuer on the day before the cum-dividend date ends. This is done by investors to obtain dividends from the issuer. As it is known that investors who own shares on the day before the cum-dividend date ends are still entitled to receive dividend distribution even though the next day the investor sells 
Alvin Fabian \& Eko Budi Santoso / Dividend Announcement Effect To Market Reaction In Non Financial Companies Listed On Indonesia Stock Exchange

JAEF, Vol. 1, No 2. April 2020 pp 57-67

or releases the shares owned, they are still entitled to receive dividends to be distributed by the issuer (Lavista et al., 2018).

In addition, the existence of a positive abnormal return before the cum-dividend date event indicates the leak of information used by investors so that investors follow the trend of information to buy these shares (Lestari et al., 2018). While the negative abnormal return value after the cum-dividend date shows that the rapid market reaction in response to the event of dividend initiations so that investors quickly sell their shares which in turn causes a decline in stock prices at the time after the announcement. Therefore, it can be concluded that there are differences in market reaction before and after the announcement of dividend initiations. This can be said if the capital market in Indonesia has a half strong form of market efficiency due to the speed of market reaction to the leak of information and the announcement of the dividend initiations contains information that is marked by differences in abrnomal returns before and after the announcement of dividend initiations.

The results of this study are in line with research by Lee \& Mauck (2016), Myrzgold \& Nowak (2016) and Yu \& Webb (2017) who state that there is a significant market reaction to the announcement of dividend initiations. Besides this research is also in line with the results of research from Lavista et al. (2018) and Lestari et al. (2018) which shows the difference in abnormal returns around the day of the cum-dividend date. Finally, this paper concludes there is no difference in market reaction before and after the announcement of dividend omissions, hence reject hypothesis one. On the other hand, there is a difference in market reaction before and after the announcement of dividend initiations, hence support hypothesis two. Implication of the study call for corporate attention to focus on good news as dividend initiations because investor respond to such information.

\section{REFERENCES}

Anwar, S., Singh, S., \& Jain, P. K. (2017). Impact of Cash Dividend Announcements: Evidence from the Indian Manufacturing Companies. Journal of Emerging Market Finance, 16(1), 29-60.

Badan Pusat Statistik. (2019). Statistik Indonesia 2019. Jakarta: Badan Pusat Statistik Indonesia.

Bahri, S. (2017). Faktor-Faktor Yang Mempengaruhi Kebijakan Dividen. JRAK: Jurnal Riset Akuntansi Dan Komputerisasi Akuntansi, 8(1), 63-84.

Cotter, J., Eije, H. Von, Faour, M., \& Muckley, C. (2018). Investor anticipation and the stock price reaction to dividend initiations and omissions, 9(2), 115-127.

Darmawan, M. (2018). Dividend Omission Announcement Effect To Market Reaction in Indonesia Stock Exchange. IJBE (Integrated Journal of Business and Economics), 2(2), 14.

Dewi \& Sedana (2018). Faktor-Faktor Yang Mempengaruhi Kebijakan Dividen Pada Perusahaan Manufaktur di Bursa Efek Indonesia. E-Jurnal Manajemen Unud, 7(7), 50- 
Alvin Fabian \& Eko Budi Santoso / Dividend Announcement Effect To Market Reaction In Non Financial Companies Listed On Indonesia Stock Exchange

JAEF, Vol. 1, No 2. April 2020 pp 57-67

66.

Dong, J., Li, H., Liu, K., \& Wu, X. (2019). The stock market reaction to dividend reductions and omissions in China. Managerial Finance, 45(3), 381-398.

Ferry, Lusiyana \& Delikartika. (2017). Faktor-Faktor Yang Mempengaruhi Kebijakan Dividen Perusahaan Non Keuangan Yang Terdaftar Di BEI. JRAK: Jurnal Riset Akuntansi Dan Komputerisasi Akuntansi, 19(4), 256-265.

Hartono, Jogiyanto. (2012). Pasar Efisien Secara Informasi, Operasional, dan Keputusan. Yogyakarta: BPFE.

Kayana, F. N., Tommy, P., \& B.Maramis, J. (2018). Reaksi Investor Pasar Modal Indonesia Tehadap Pengumuman Dividen ( Studi Kasus Pada Perusahaan Asuransi Yang Terdaftar Di Bursa Efek Indonesia Tahun 2016-2017 ). Jurnal EMBA, 6(3), 1208-1217.

Lavista, E., Utami, E. S., \& Puspitasari, N. (2018). Perubahan Abnormal Return Dan Volume Perdagangan Pada Hari Sekitar Cum-Dividend Date Di Bursa Efek Indonesia. Bisma, 12(3), 403.

Lee, B. S., \& Mauck, N. (2016). Dividend initiations, increases and idiosyncratic volatility. Journal of Corporate Finance, 40(9), 47-60.

Lestari, A. R., Arif, A., \& Wijayantini, B. (2018). Relevansi Cum-Dividend Date Dengan Perubahan Harga Saham Pada Sektor Manufaktur Di Bursa Efek Indonesia. Jurnal Balance, 15(2), 90-110.

Mrzygłód, U., \& Nowak, S. (2017). Market reactions to dividends announcements and payouts. Empirical evidence from the warsaw stock exchange. Contemporary Economics, 11(2), 187-204.

Pramana, K. S. (2017). Reaksi Pasar Terhadap Pengumuman Dividen Di Bursa Efek Indonesia. Jurnal Fakultas Ekonomi dan Bisnis Universitas Udayana, 6(11), 6324-6356.

Pertiwi, N. P. A., \& Wirama, D. G. (2019). Reaksi Pasar atas Deviden Initiation dan Deviden Omission. E-Jurnal Akuntansi Universitas Udayana, 26(2), 1190-1214.

Sri Rahayu, N., \& Dana, I. (2016). Pengaruh Eva, Mva Dan Likuiditas Terhadap HargaSaham Pada Perusahaan Food and Beverages. E-Jurnal Manajemen Universitas Udayana, 5(1), 443-469.

Sugiyono. (2015). Metode Penelitian Pendidikan (Pendekatan Kuantitatif, Kualitatif, dan $R \& D$. Bandung: CV. Alfabeta.

Tandio, T., \& Widanaputra, A. (2016). Pengaruh Pelatihan Pasar Modal, Return, Persepsi Risiko, Gender, Dan Kemajuan Teknologi Pada Minat Investasi Mahasiswa. E-Jurnal Akuntansi, 16(3), 2316-2341.

Yu, S., \& Webb, G. (2017). The information content of dividend initiation announcements: The case of information technology firms. Managerial Finance, 43(7), 794-811. 
Alvin Fabian \& Eko Budi Santoso / Dividend Announcement Effect To Market Reaction In Non Financial Companies Listed On Indonesia Stock Exchange

JAEF, Vol. 1, No 2. April 2020 pp 57-67

\section{Appendix}

Table 1

Descriptive Statistics Dividend Omissions

\begin{tabular}{|c|c|c|c|c|c|c|}
\hline & $\mathbf{N}$ & Minimum & Maximum & Mean & Median & $\begin{array}{c}\text { Std. } \\
\text { Deviation }\end{array}$ \\
\hline $\begin{array}{l}\text { AAR Before } \\
\text { Announcement } \\
\text { Dividend } \\
\text { Omissions }\end{array}$ & 26 & -0.02 & 0.03 & 0.0015 & $-0,00056$ & 0,00925 \\
\hline $\begin{array}{l}\text { AAR After } \\
\text { Announcement } \\
\text { Dividend } \\
\text { Omissions }\end{array}$ & 26 & -0.03 & 0.06 & 0.0023 & 0,00067 & 0,01728 \\
\hline $\begin{array}{l}\text { Valid N } \\
\text { (listwise) }\end{array}$ & 26 & & & & & \\
\hline
\end{tabular}

Source: Data processed (2019)

Table 2

Descriptive Statistics Dividend Initiations

\begin{tabular}{|c|c|c|c|c|c|c|}
\hline & $\mathbf{N}$ & Minimum & Maximum & Mean & Median & $\begin{array}{c}\text { Std. } \\
\text { Deviation }\end{array}$ \\
\hline $\begin{array}{l}\text { AAR Before } \\
\text { Announcement } \\
\text { Dividend } \\
\text { Initiations }\end{array}$ & 45 & -0.02 & 0.04 & 0.0019 & 0,00062 & 0,01315 \\
\hline $\begin{array}{l}\text { AAR After } \\
\text { Announcement } \\
\text { Dividend } \\
\text { Initiations }\end{array}$ & 45 & -0.04 & 0.03 & -0.0060 & $-0,00743$ & 0,01407 \\
\hline $\begin{array}{l}\text { Valid N } \\
\text { (listwise) }\end{array}$ & 45 & & & & & \\
\hline
\end{tabular}

Source: Data processed (2019) 
Alvin Fabian \& Eko Budi Santoso / Dividend Announcement Effect To Market Reaction In Non Financial Companies Listed On Indonesia Stock Exchange

JAEF, Vol. 1, No 2. April 2020 pp 57-67

Tabel 3

Dividend Omissions Normality Test Results

\begin{tabular}{cccc}
\hline & \multicolumn{3}{c}{ Kolmogorov-Smirnov } \\
\cline { 2 - 4 } & Statistic & df & Sig. \\
\hline AAR & 0,21 & 52 & 0,000 \\
\hline
\end{tabular}

Source: Data processed (2019)

Tabel 4

Dividend Initiations Normality Test Results

\begin{tabular}{cccc}
\hline & \multicolumn{3}{c}{ Kolmogorov-Smirnov } \\
\cline { 2 - 4 } & Statistic & df & Sig. \\
\hline AAR & 0,199 & 90 & 0,000 \\
\hline
\end{tabular}

Source: Data processed (2019)

Tabel 5

First Hypothesis Testing Results

\begin{tabular}{|c|c|}
\hline \multicolumn{2}{|c|}{ Wilcoxon Signed Ranks Test } \\
\hline & $\begin{array}{c}\text { After- } \\
\text { Before }\end{array}$ \\
\hline$Z$ & $-0,278$ \\
Asymp. Sig. (2-tailed) & 0,781 \\
\hline
\end{tabular}

Source: Data processed (2019)

Tabel 6

Second Hypothesis Testing Results

\begin{tabular}{|c|c|}
\hline \multicolumn{2}{|c|}{ Wilcoxon Signed Ranks Test } \\
\hline & $\begin{array}{l}\text { After- } \\
\text { Before }\end{array}$ \\
\hline $\mathrm{Z}$ & $-2,448$ \\
Asymp. Sig. (2-tailed) & 0,014 \\
\hline
\end{tabular}

Source: Data processed (2019) 